\title{
The Rise and Decline of Japanese Pacifism
}

\author{
Yuan Cai \\ University of Adelaide
}

\begin{abstract}
The Japanese pacifist constitution has been a symbol of Japan's commitment to peace and more importantly its renunciation of wartime militarism. There has been strong support for its continuing existence amongst the Japanese populace despite persistent attempts by the Japanese government to amend it. However, the prevalent pacifist sentiment is showing signs of fading vitality in recent times.

This article purports to examine the underlying forces that contributed to the development and the decline of Japanese pacifism. A host of domestic and international factors were responsible for the growth of pacifism and its subsequent decline, but only three important domestic factors will be examined in detail: the concept of victimhood in the development of pacifism and its implication for its continuing strength, the importance of peace education and the role played by the influential Japan's Teachers' Union on the formation of pacifist conscience and finally, the influence of leftist organisations on the organised peace movement.
\end{abstract}

\section{Keywords}

pacifism, atomic victimhood, Japan's Teachers' Union, Gensuikyo, Japan Socialist Party

\section{Introduction}

The Japanese pacifist constitution, unparalleled in its idealistic vision for the renunciation of war as an instrument of the state, has been the battleground of competing political forces in Japan ever since its conception in 1946. The conservatives' creative interpretation of the constitution largely evaded the spirit of absolute pacifism embedded in the renowned Article IX. The Japanese people have exhibited an admirable allegiance to the ideals of Article IX throughout the post-war period: the conservatives' agenda for outright constitutional amendment was thwarted by the prevalent pacifist sentiment. However, in recent times pacifism is showing signs of fading vitality. 
.

The purpose of this article is to examine the underlying forces that contributed to the development and the decline of Japanese pacifism. A host of domestic and international factors were responsible for the growth of pacifism and its subsequent decline, but only three important domestic factors will be examined in detail: the concept of victimhood in the development of pacifism and its implication for its continuing strength, the importance of peace education and finally the influence of socialism on the organised peace movement.

The study of driving forces behind the rise and decline of pacifism in Japan provides a valuable insight into its past and future. The examination of key concepts such as victimhood, peace education and socialism will lead to an appreciation of what contributed to one of the most dramatic social-political transformations in the twentieth century; the conversion of Japanese society once wedded to militarist cults into that of a peace loving culture. The future sustainability of pacifism could be revealed through the prism of the three important themes mentioned above.

The concept of victimhood is essential to understand the development of pacifism. The horrendous suffering endured by ordinary Japanese citizens and especially that of Hibakusha (the atomic bomb victims from the cities of Hiroshima and Nagasaki) defined the pacifist character of the Japanese post-war society. James Orr regards atomic victimhood as the 'first powerfully unifying national myth after defeat' and the rallying point for the Japanese pacifist movement. However, it must be noted that fear-induced pacifism based on the notion of victimhood is inherently fragile. If the concept of victimhood can be expressed mathematically, this would take the form that suffering equates 'never again'. The question worth considering is what if direct experience of the suffering component of the pacifist equation is disappearing, as the new generation of Japanese grow up in the affluence of post-war prosperity. Would they still find the messages of victimhood, hardship and suffering relevant to the understanding of pacifism?

This article will also explore the central importance of peace education in the development of pacifism. A true pacifist cannot simply justify his identity purely on the basis of experience of suffering without condemning the intrinsic evilness of war. Fear alone cannot sustain the pacifist identity: a genuine recognition of the evil of war is at the heart of true and sustainable pacifism. The fluctuating fortunes of peace education will be examined through the lens of the history textbook controversy and the fortunes of Japan's Teachers' Union.

The leftist forces were instrumental in the organised peace movement throughout the post-war period and they played an especially important role in the anti-nuclear movement. However, their involvement proved to be a double-edged 
sword, ideologically-driven disputes between the Socialist Party and the Communist Party compromised the non-partisanship of the movement and hence its appeal and influence. On the other hand, organisational ability and mobilisation power of various leftist forces ensured the continuation of the movement beyond the initial burst of popular zeal.

\section{The Mythology of Victimhood and Pacifism}

\section{The Nature of Pacifism in Japan}

The birth of Japanese pacifism was a reflection of the extraordinary circumstance of its conception: a war-weary and destitute population eagerly embraced pacifism out of desperation. It could be said that Japanese pacifism is essentially a celebration of its own victimhood, the appalling suffering of Japanese citizens and especially that of Hiroshima and Nagasaki who were considered martyrs, sacrificed on the altar of peace. Hiroshima and Nagasaki's importance to Japanese pacifism could singularly be compared with the significance of Auschwitz to the Zionist movement. This section will explore the gradual development of the myth of victimhood through various mediums such as literature and arts. The future sustainability of pacifism based on the notion of victim conscience will be discussed in the context of generational changes in Japan.

It is important to distinguish between the natures of pacifism in Japan and what it stands for within Western philosophical tradition. According to the historian Henry J. Cadbury, pacifism in the strict sense of absolute and unconditional rejection of war or any form of violence originated with Christianity, primitive Christians believing war or participation in the military is irreconcilable with the teaching of the Gospels. ${ }^{1}$ This religion-inspired pacifism was further fused with the liberal political ideals from the European Enlightenment; as a result the most active pacifist groups are to be found in Europe and North America. In the case of Japan, Christians played a leading role in the development of pre-war pacifism, though it remained a much-marginalized movement with few members. Some of the most influential Japanese pacifists at the time were all Christians; their advocacy for pacifism remained largely a literary debate rather than a mass movement that characterized post-war pacifism. ${ }^{2}$ 
.

\section{Victim Consciousness: the Ideology of Politics}

The genesis of post-war Japanese pacifism was rooted firmly in the ruins, suffering and hardships inflicted by the prolonged war. The economic deprivation and human suffering caused by the war fundamentally shaped people's understanding of questions of war and peace, and for the ordinary Japanese support for pacifism is an expression of their desire not to relive such horrific experiences. This 'never again' sentiment crystallized in the form of the collective victimhood of the Japanese people, thus the determination to resist war can be understood as a pragmatic move to protect their own well-being. This perception of war and peace differs fundamentally from the western concept of pacifism; Japanese pacifism is not based on religion-inspired ideals of non-violence, moral abhorrence of the barbarism of war, and respect for fundamental human rights. Ian Buruma described Japanese pacifism as the 'Cult of Hiroshima', and its defining characteristics as the 'black corpses' (atomic bomb victims). ${ }^{3}$

The mythology of victimhood was perpetuated in many different forms such as literature, films, arts, and the peace movement. A disproportionate amount of post-war literature on pacifism is devoted to the wartime suffering of the Japanese civilians from atomic bombs, firestorms caused by air raids, and general privations such as hunger. The public dialogue on pacifism reached its zenith in the discussion of the atomic victimhoods of Hiroshima and Nagasaki, and according to the information collected by the Hiroshima Prefectural Office, writings on atomic bomb experiences in relation to the city alone numbered 500 published books and articles, and 2,234 written testimonials by 1971. ${ }^{4}$ In 1983, major literary writings pertaining to the experiences of atomic victims were published in a massive 15 volume collection entitled Nihon no Genbaku bungaku (Japanese atomic bomb literature). ${ }^{5}$

The critically acclaimed novel Black Rain (Kuroi Ame) by Ibuse Masuji is arguably the most famous and successful of the atomic bomb literature, well over a million copies were sold according to 1981 figures. A survey of leading Japanese intellectuals in 1987 acknowledged Black Rain as the most influential book written on any subject since $1945 .{ }^{6}$ Black Rain is the story of the odyssey experienced by Shigematsu's family in their attempt to find a prospective husband for Yasuko, the niece of Shigematsu. Unfortunately, the marriage prospects of Yasuko are repeatedly thwarted by the rumour that Yasuko was a victim of radiation sickness as she was working at the kitchen of the Second Middle School Service Corp at the time of the explosion. ${ }^{7}$ When Yasuko had the

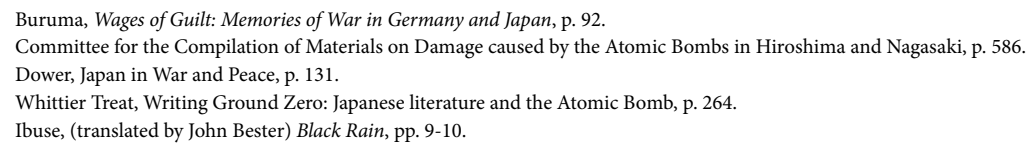


chance of a match, which seemed 'almost too good to be true', Shizuma sent a certificate of good health to the go-between in a desperate effort to fend off the insidious rumour. However, this pre-emptive strike disastrously backfires as it arouses suspicion from the go-between; Yasuko's whereabouts on the day of the explosion became the subject of an investigation. The circumstances inspired Shigematsu to transcribe his niece's diary from August; to his great astonishment he learnt from Yasuko that she was plagued with radioactive black rain, and then her whole family conspired to cover up this unfortunate episode of Yasuko's life. However, before he could do his work the rumour became a self-fulfilling prophecy, the onset of symptoms leading to abrupt termination of the marriage talk.

This novel describes the impact of war on the innocent civilian population of the home islands. The main characters are all civilians, men too old for the military, women and children; Ibuse Masuji did not present the suffering of the hibakusha as anything unique compared with the misery endured by the population at large; the desperate escape from firestorms induced by the atomic explosion resonating with the experiences of the ordinary Japanese in the firestorms caused by the countless American raids. Shigematsu and Yasuko's problems though complicated by their status as hibakusha, were fundamentally similar to the difficulties encountered by the people after the war. ${ }^{8}$ In this regard, Black Rain helped to integrate the experience of Hiroshima into the national ideology of victimhood, the vivid depiction of the suffering of civilians that resonated with readers' own experiences of the horrors of the war helped to build and strengthen the sense of victimization.

The mythology of victimhood also formed the locomotive force behind the Japanese peace movement. From some of the earliest declarations on peace to the latest anti-nuclear resolutions pledged by the pacifists, a sense of unique atomic victimhood was the common denominator. For example, in 1945 when the Organizing Committee for the Hiroshima Assembly to Protect the Peace issued a moving communiqué that declared, 'We pledge to stand in the front lines of support. To do so is a solemn responsibility laid upon us, who first experienced an atomic bombing. It is also our right to do so.' ${ }^{9}$ This victimhood bestowed the Hiroshima citizens with a special sense of mission to campaign for a world free of nuclear weapons. In a letter of protest published by the Nagasaki Council Against Atomic and Hydrogen Bombs in the Los Angeles Times in 1962 against the resumption of nuclear testing by the United States, chief director Kobayashi wrote that 'we have protested against President Kennedy's decision to resume nuclear testing because [of] our tragic experiences in Hiroshima, Nagasaki 
.

and Bikini..... ${ }^{10}$ In the latest peace resolution at the 2005 World Conference Against A \& $\mathrm{H}$ Bombs, the declaration commenced with reference to the suffering of hibakusha, and it strongly emphasized the fact that 'Japan [is] the only nation that has suffered from the use of nuclear weapon in war. ${ }^{11}$

\section{The Decline of Victim Consciousness and the Future of Pacifism}

If the birthplace of pacifism was among the ruins of an utterly defeated Japan, its ultimate deathbed must be the glittering new Japan built atop the ruins. Japan's meteoric rise as one of the largest economies in the world has been described as an economic miracle; and the Japanese people today enjoy one of the highest living standards in the world. Any first time foreign visitors will be awestricken by the modernity of Japan, its glittering neon lights, high-rise skyscrapers, and the oversized electronic advertising boards. There is very little in Japan to remind foreign visitors and young Japanese of the devastation of the war at the end of 1945. Even visitors to Hiroshima and Nagasaki will be struck by their apparent normalcy. Apart from the A-bomb dome and the peace park, there is very little to differentiate these two cities from other Japanese metropolitan centres. The corporate buildings, neon lights and department stores dominate downtown Hiroshima. The imposing structure of the Hiroshima baseball stadium, home to the celebrated Hiroshima Carp, replete with amplifiers and lights offer little reminder of the hellish landscape it is built on. So complete was the reconstruction in Hiroshima, the hibakusha are committed to preserve the physical remnants of the 1945 nuclear holocaust. ${ }^{12}$ They fear that with the disappearance of the physical scars of the war, the younger generation will forget the disaster that befell the city 60 years ago.

In a Japan Broadcasting Corporation (NHK) survey in 2002, it revealed that most of the Japanese youth were ignorant of Japan's modern history and had little knowledge of the post-war conditions. ${ }^{13}$ The generational change in Japan is undermining the fragile foundation of pacifism in Japan. It is a universal phenomenon that those who had lived through war and its immediate aftermath developed a very different worldview and values from those who had only known prosperity and Japan is no exception. Given the particularly horrible conditions in wartime Japan and its aftermath, the generational perception on war and peace is even more pronounced. The older generation, those who are 50 years old or above generally regard issues on war and rearmament with great suspicion, if not outright resentment, and on the other hand the younger generations

\footnotetext{
Naeve, Friends of Hibakusha, p. 121.

60 Years since the Atomic Bombing: Time to Develop Actions and Cooperation for a Nuclear Weapon-Free, Peaceful, Just World, 2005 , the 2005 World

Conference against A \& H Bombs, Hiroshima, Japan.

12 Gerson, With Hiroshima Eyes: Atomic War, Nuclear Extortion and Moral Imagination, p. 26.

13 Generational Change in Japan: Its implication for U.S-Japan Relations 2002, p. 6.
} 
born in the peace and prosperity of post-war Japan tend to be much less sensitized to this issue.

The most enduring feature of Japan's wartime suffering and the key rallying point of post-war pacifism and the peace movement are also showing signs of weakening vigour. The peace memorial services at Hiroshima and Nagasaki that were once regarded as sacred touchstone events on the Japanese national calendar are losing their appeal to the Japanese public. The Peace Commemoration event on August 6 at Hiroshima in 2005 drew a crowd of 7000, but it paled in comparison to previous events at this same Mecca of Peace that exerted a pull on tens of thousands of peace pilgrims. Professor Ryuso Tanaka of the Hiroshima Peace Institute noticed that the number of Japanese school children who visit the Peace Park on school excursions had declined sharply in recent years, and the 'oblivion to the Hiroshima memory' is becoming a nationwide phenomenon. Sadako's famous paper cranes, symbols of peace the world over have been set on fire repeatedly by students on their excursion trips. Not even a specially constructed glass screen could save it from vandalism. ${ }^{14}$

A long time resident of Nagasaki also recalled in an interview that the annual commemoration event at Nagasaki no longer makes headlines in the local news over the past few years, even the local residents appear to be more preoccupied with such pressing problems as employment and schooling over peace and war. ${ }^{15}$ 'We are faced with the challenge of conveying this experience to the next generations', said Noriyuki Masuda, associate director of the Hiroshima Peace Memorial Association. 'At some point we realized that what we had was a crisis involving young people's consciousness. We have been facing a change in attitudes and a decline of interest in Japan as a nation. ${ }^{16}$ This declining interest in Hiroshima and its compelling story of death and survival is evident to Mrs Setsuko Iwamoto, who is both a hibakusha and a lecturer for 18 years to visiting students at the Peace Museum. She said, with each passing year, the stares of the students grow blanker and blanker, and their questions about atomic bombing grow more stilted, appearing more rehearsed than heartfelt. ${ }^{17}$ The real challenge for Hiroshima and Nagasaki is how to keep alive the memory of the atomic bomb victims, with the gradual withering of the surviving hibakusha. The people of Japan in general and residents of Hiroshima and Nagasaki in particular need to find a way to perpetuate the peace message without the living voice of hibakusha.

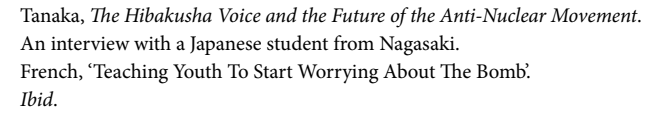


.

\section{Peace Education and Pacifism}

Having explored the significance of the popular desire that never again should they relive the horrors of war as the driving force behind pacifism in Japan, it is also imperative to examine another pillar of the development of pacifism in post-war Japan, namely the importance of peace education in fostering a pacifist spirit among the younger generation. The post-war democratization of Japan's once authoritarian educational system had provided a solid foundation for the growth of pacifism, its emphasis on democracy and peace had imbued a pacifist spirit in a generation of Japanese. However, the changing international geopolitical and domestic political situation witnessed the gradual erosion of peace education in the education system. The conservatives' desire to roll back the post-war education reforms and to re-introduce a more nationalistic curriculum was met with equal determination from the opposition forces. The perpetual battle between the conservative education bureaucrats and the progressive Japan Teachers' Union or Nikkyoso is an excellent example. The gradual corrosion of peace education could be viewed through the lens of the dwindling influence and membership of the Nikkyoso, the guardian angel of peace education, coupled with a general retreat from the post-war educational goals of 'democracy and peace', which contributed to the gradual decay of pacifist sentiment, especially among the younger generation.

\section{Peace Education and the Rise of Pacifism}

After Japan's unconditional surrender to the Allies, the American Occupation authority had the messianic belief in the total transformation of Japan from a totalitarian militaristic state into a democratic and peace loving country. This desire was expressed explicitly in the authoritative policy statement titled 'United States Initial Post-Surrender Policy for Japan', some of the primary objectives were 'abolition of militarism and ultra-nationalism in all their forms; the disarmament and demilitarization of Japan,.... and encouragement and support of liberal political tendencies in Japan. ${ }^{18}$ Education reform was considered indispensable for the implementation of the above objectives, and the Americans saw the pre-war Japanese education system as an incubator for a nation of ultra-nationalist samurais and as one of the perennial causes of Japan's war of aggression. ${ }^{19}$

A host of policies were implemented by the Occupation Authority to eliminate militarism and ultra-nationalism from the educational system: right-wing teachers and educators were forced to resign from their jobs, the use of militaristic and nationalistic

Beauchamp and Vardaman, Japanese Education Since 1945: A Documentary Study, p. 51.

19 Beauchamp, Windows on Japanese Education, p. 29. 
textbooks were banned in schools, the teaching of moral education (Shushin), Japanese history and geography were eliminated and all military training at the schools was suspended. ${ }^{20}$ The Americans accomplished the demolition of the physical vestiges of the pre-war militaristic education system swiftly; but the creation of a democratic Japan and a nation that 'would never want to go to war again' was a far more intricate task to achieve.

In order to democratize the Japanese education system, the United States Education Mission composed of a very distinguished panel of American scholars and educators was sent to Japan to advise General MacArthur on the delicate issue of education reform. The recommendations made by the Mission exerted a great influence on the establishment of the Fundamental Law of Education (FLE) and the School Education Law (SEL). The essence of the Mission's recommendations was the democratization of Japan's highly centralized education system, and to transfer power from the mighty Ministry of Education to the local communities and the popularly elected school boards. ${ }^{21}$ It must be noted that educational reform was not a unilateral imposition by the victor on the vanquished, the Japanese themselves had engaged in some profound soul-searching after the disastrous war. According to the Educational Policy for the Construction of a New Japan, the first policy paper issued by the Ministry of Education after the war, the primary objective of the post-war Japanese education system was to 'abolish militaristic attitudes while firmly preserving the national polity and to create in their place attitudes conductive to a peaceful nation'. It also emphasized the need to cultivate 'a commitment to the love of peace.'2 The senior members of the Japanese government, including the Education Minister, repeatedly expressed their support for this policy priority. Tanaka Kotaro (MOE) told the Education Reform Committee in 1946 that the objective of education reform was 'the establishment of a democratic system of education that finds its values in the ideals of truth and peace.23

With the repudiation of the Imperial Rescript on Education, and its associated militaristic and ultra-nationalistic principles, the post-war Japanese educational system was basking in thelights of liberalism and pacifism. The FLE stated in its Aim of Education of the necessity to educate young people to 'love truth and justice' and to have a 'deep sense of responsibility' ${ }^{24}$ and various other democratic and pedagogical aspirations; these objectives might seem thoroughly commonsensical to us today or even totally unexceptional, but these goals were absolutely antithetical to everything that Japanese education had stood for. During the initial period of Occupation, when the idealism of Washington to transform Japanese people into a democratic and pacifist people had not

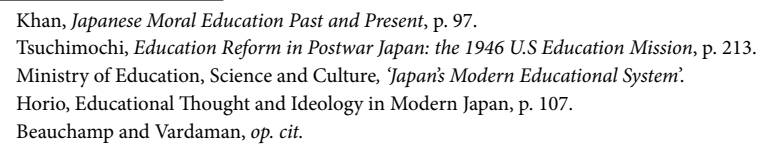


.

yet been tainted by the realities of the coming Cold War, history textbooks published in this period reflected the above ideals through earnest discussion and reflection of Japan's war responsibility that only ended a few years ago. This position was clearly marked in the Ministry of Education's publication 'Guide to New Education in Japan' for teachers, it states unequivocally 'the responsibility of the war should be borne by the Japanese nation and they must apologize most humbly to the world for the sins they have committed.' ${ }^{25}$ This repentant stance was further highlighted in a 1949 Ministry of Education publication, which stated, 'Japan and Germany must accept the greatest responsibility for World War II, which caused vast suffering, distress, and dislocation to the world.' ${ }^{6}$ The occupation era textbooks had left no stone unturned, even the role of the emperor was discussed. The emperor was described as an active participant in the war and many people had been sacrificed in his name. ${ }^{27}$

Educational policy, especially in relation to peace education, took an overtly conservative turn after 1950, when the heightened political atmosphere of the Cold War re-oriented the occupation policy from that of democratization to establishing a bulwark against Communism. Under the stewardship of the conservative Prime Minister Shigeru Yoshida, an Advisory Committee on Government Laws was established to examine the suitability of American-introduced laws. One of the targeted areas was the education law, the committee recommended reinstating standardized and certified textbooks in schools. ${ }^{28}$ The conservatives wanted to downplay and sanitize Japan's aggressive past, to re-introduce patriotic education and to moderate the vigour of post-war democratic and pacifist education. ${ }^{29}$ The fluctuating fortunes of the Japanese peace education programme can be best captured through the relentless battle between the conservative LDP government and the progressive Nikkyoso.

\section{Nikkyoso: the Waning Guardian Angel of Peace Education}

The Japan Teachers' Union or Nikkyoso was one of the most important articulators of progressive culture in post-war Japanese society and it was also one of the most influential promoters of peace education within the education system. In the post-war decades, Nikkyoso had persistently acted as a countervailing force to the conservative Ministry of Education's agenda to adulterate the progressive reform education policies introduced by the Americans during the Occupation period. The teachers affiliated with Nikkyoso played an important part in educating the Japanese youth about the

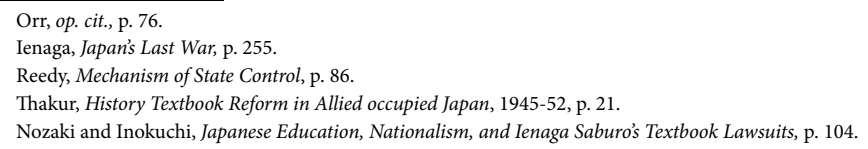


importance of peace, however their influence has been declining over the years due to dwindling membership and other factors.

The Japan Teachers' Union was founded on June 8, 1947 as an amalgamation of a disparate group of leftist teachers' unions across Japan. According to the report compiled by the American occupation authority, the newly founded Nikkyoso embraced nearly all of the 400,000 teachers in Japan, with an overwhelming majority sympathetic to the leftist ideology. ${ }^{30}$ The Nikkyoso was created to advance a multitude of objectives: to improve the economic situations of the teachers, and to safeguard against the renewal of militarism and ultra-nationalism in schools. The Nikkyoso announced five platforms on peace in 1950: 'Establishment of democratic rights, opposition to military bases, independence of ethnic groups, signing of the peace treaty, and the establishment of effective peace education' ${ }^{31}$ The promotion of peace education was one of the primary objectives pursued by the Nikkyoso and it was enshrined in its Code of Ethics, Article I of the Code emphasized the 'historical tasks of protecting peace. This article resonated with one of the most appealing slogans used by the Nikkyoso during the post-war period, 'Never again send children to the battlefield'. ${ }^{32}$

The leftist-oriented teachers frequently introduced peace themes into the classrooms and often outside the standard curriculum, one of the most famous cases of this kind occurred in Ashigaoka, a middle-class suburb of Kyoto. When the local teachers' union introduced a special program of peace education in the schools, a small group of alarmed parents lodged a complaint, and it charged that teachers argued against Japan's rearmament and the presence of U.S military bases during regular class hours. In response to the complaint, the district school superintendent attempted to transfer the teachers most responsible for the peace education. However, the rejection of the transfer orders resulted in their dismissal. The Nikkyoso and a large group of sympathetic parents vehemently opposed the government's action. Subsequently the conservative LDP government introduced new legislation in the Diet to restrict any future occurrence of 'politically-biased' education. ${ }^{33}$

It seemed that a large number of Nikkyoso affiliated teachers engaged in peace education in and out of classrooms. A documentary on Japanese non-governmental organizations supporting lawsuits brought by Chinese and Korean civilians seeking compensation over the wartime atrocities committed by the Japanese government revealed a disproportionately large number of teachers and educators. In an interview,

\footnotetext{
Duke, Japan's Militant Teachers: A History of the Left-Wing Teachers' Movement, p. 75.

Okano and Tsuchiya, Education in Contemporary Japan: Inequality and Diversity, p. 32.

Thurston, Teachers and Politics in Japan, pp. 88-89.

Cummings, Education and Equality in Japan, pp. 57-58.
} 
.n.m.n. of

two NGO activists, both retired teachers, told the journalist it is their duty to inform the next generation about wartime atrocities and teach them the barbarity of war and the sanctity of peace. ${ }^{34}$ In numerous interviews with young Japanese, it was not hard to gain an impression that the supporters of the pacifist constitution were overwhelming and deeply influenced by their teachers. One student from Nagoya recalled a case where his teacher told the class, because of the pacifist constitution that they would never have to go through the horror of war again. Another student remembered when his teacher devoted an entire lesson to Japan's wartime atrocities, a subject that was not normally covered in the curriculum. ${ }^{35}$

The Nikkyoso was engaged in a constant battle against the conservative government's policies that would negatively impact on peace education. One of the extremely controversial issues was the vexing problem of textbook control. In 1956, the government introduced a bill that would not only strictly limit the number of textbooks that could be used throughout the country, but also empowered a prefectural selection committee to choose the book. If this bill were enacted, this would allow significant leverage on the part of the conservative government to influence the content of textbooks and undermine peace education. The Nikkyoso vehemently opposed the bill, and it organized a massive strike of over a half million teachers that successfully forced the government to retreat. ${ }^{36}$ This incident amply demonstrated the importance of Nikkyoso in the post-war education system as a counterweight to the conservative government. However, Nikkyoso's victory was largely undermined by the government's strategy to use a textbook screening system to filter its 'undesirable' content.

The influence of Nikkyoso has been declining over the years; one of the clearest indicators is the dwindling membership. The Nikkyoso membership as a percentage of educational personnel had declined from $86.3 \%$ in 1958 to $48.5 \%$ in 1987 , and this trend is still persisting. ${ }^{37}$ A host of factors contributed to this decline in membership, the dramatic improvement in teachers' salary during the post-war period reduced the incentive for the teachers to join the union, which was one of the most important objectives of the Nikkyoso. The rise of an apolitical generation of Japanese teachers who had no experience of the memory of war or the repressive educational system in the pre-war years resulted in a loss of the sense of mission to educate the next generation of the importance of peace. ${ }^{38}$ The decline in the influence of Nikkyoso and the increasing adamance of the conservative government to re-introduce a more

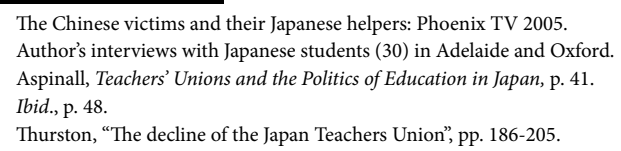


nationalistic education agenda eroded the post-war foundation in peace education and thus impacted negatively on the growth of pacifism.

\section{Red Pacifism? The Rise and Fall of Left-wing Influence on the Development of the Japanese Pacifist Movement}

Since the advent of pacifism in Japan, it had a very strong imprint of socialism. Some of its earliest advocates were strongly influenced by Marxist ideals on the solidarity of international proletarians. These early peace pioneers sowed the seeds of peace that would in turn germinate in the fertile soil of post-war democratic reforms. Various left-wing parties and groups became the torchbearers of constitutional pacifism and they provided the organizational backbone for the pacifist movement throughout much of the post-war period. In fact, the left-wing groups and especially the Japan Socialist Party assumed the mantle as the guardian of Japan's pacifist constitution until its disbandment in 1995. However, the infightings of the various left-wing groups and especially the struggle between the JSP and JCP significantly lessened the mass appeal of the movement, and the politicization of an initially non-partisan movement contributed to the relative decline of pacifism in Japan.

\section{JSP and JCP Inter-party Divisions and the Decline of the Anti-nuclear Lobby (Gensuikyo)}

In the aftermath of the catastrophic war that devastated Japan, there was a broad consensus among the groups across the leftist political spectrum in Japan of the need to renounce its militarist past and to embrace democracy and pacifism. Soon after the war, a group of leading socialists from the pre-war era convened together to form the Nihon Shakaito (JSP) ${ }^{39}$. They unanimously agreed on a general policy platform of democracy, socialism and pacifism. ${ }^{40}$ The Communist Party of Japan was the only political party with an unblemished record on its principled resistance to the pre-war militarism, and it still strongly adheres to the principles of constitutional pacifism today. ${ }^{41}$

However, the desire to consecrate Japan with the olive crown was not matched by agreement on the pathway to obtain that cherished goal, the socialists believed in the 'positive neutrality' that was in the spirit of the Non-alignment Movement. ${ }^{42}$ The

\footnotetext{
39 It must be noted there is an inconsistency in the usage of the term JSP, it is a direct transliteration of the Japanese words Nihon Shakaito. However, the official English title of the party is actually Social Democratic Party of Japan (SDP). Throughout this paper, the term JSP will be used.

40 Cole, Totten and Uyehara, Socialist Parties in Postwar Japan, p. 5.

41 Stockwin, Dictionary of the Modern Politics of Japan, p. 123.

42 There was no consensus among the socialists on the pathway to achieve pacifism; there were three major factions within the JSP with conflicting views on the means to achieve pacifism. This ranged from the right-wing socialist's preference for a closer relationship with the West to the left-wing socialist 'Third Road Thesis, the complex interplay of the intra-party differences will be discussed in detail in the next section of this chapter.
} 
.

Communists and their sympathizers openly advocated the ideologically tainted 'Peace force thesis', which supports the Communist camp as the 'force of peace' against the Americans and their allies. The constant bickering between the two parties significantly damaged the unity and the credibility of the anti-nuclear movement, which eventually resulted in disintegration of the movement into two hostile camps. More importantly, the ideological encroachment of the initially non-partisan anti-nuclear movement by the JSP and JCP significantly lessened its mass appeal to the Japanese public that was weary or even hostile to communism; this fear was strengthened by the gravitation of socialist policy towards the left. However, the organizational skills and determination displayed by the various leftist groups, and especially by the JCP ensured the perpetuation of the movement until the present day.

One of the most prominent expressions of pacifism in Japan during the postwar period was the anti-nuclear movement which was triggered by the 'ashes of death' from the American nuclear tests on the Bikini Atoll. The Japanese fishermen aboard the Lucky Dragon were exposed to radioactive fallout from the American nuclear test, and one fisherman suffered fatal injuries. This incident sparked off a nationwide furore, and it was widely covered by the Japanese media. ${ }^{43}$ The death of the crewmember also triggered a large-scale protest on the $1^{\text {st }}$ of May, with protesters holding signs such as 'Against re-armament and support for pacifism. ${ }^{44}$ Most significantly, in the same month the housewives of the Suginami Ward of Tokyo organised the famous 'Suginami Appeal', which collected over 30 million signatures.

This groundswell of public protest generated momentum to convene the first ever World Conference against Atomic and Hydrogen Bombs and in 1955 on the tenth anniversary of the atomic bombing of Hiroshima, 30,000 people including a small foreign contingent participated in this conference. ${ }^{45}$ This conference was sponsored by many influential Japanese public figures including the former Prime Minister Tetsu Katayama, the President of the Japan Academy of Science Saburo Yamada, the Presidents of Japan YMCA, the All-Japan Buddhist Associations and the International Trade Promotion Commission. ${ }^{46}$ During the Conference, three broad goals were announced: prevention of nuclear war, abolition of nuclear weapons, and relief and solidarity for the Hibakusha. Building on the success of the conference, on the $19^{\text {th }}$ of September the organizers of the event established a permanent body called the Japan Council against Atomic and Hydrogen Bombs (Gensuikyo) to perpetuate the struggle for the total abolition of nuclear weapons. ${ }^{47}$

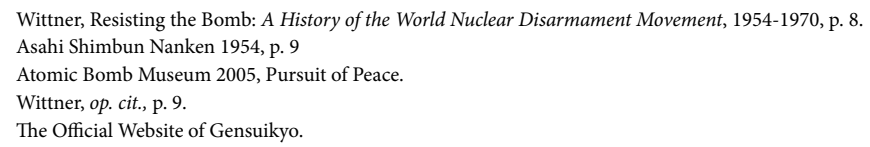


Gensuikyo became one of Japan's most important and enduring mass movements. Its activities were vigorously espoused by the Japanese public, and it drew supporters from every walk of life in Japan. It has been instrumental in keeping Japanese people's 'nuclear allergy' sensitive and is an important pressure group to oppose any attempts by the government to re-arm the Self-Defense Force with advanced offensive capabilities, especially nuclear weapons. In addition, it continuously re-energizes a social movement that is not necessarily self-sustaining. Even though Gensuikyo had a very strong activist base comprised of members of the powerful Socialist Party and its affiliated trade unions and some communists, its initial activities were largely immune from the partisan politics that later stigmatized its reputation throughout the turbulent Cold War period.

The Socialist and Communist Parties both in principle committed to constitutional pacifism and both professed their support for the anti-nuclear movement. However, there was a fundamental difference in their ideological approaches to the understanding of pacifism. As early as 1949, The JSP officially adopted a foreign policy of permanent neutrality. This policy was formally introduced in the following terms. '... Our Party, having regard to the neutral status established by the Constitution, opposes the conclusion of any military or political agreement with a particular country or a particular group of countries." ${ }^{48}$ This JSP policy is also known as the 'Third Road Thesis', which was heavily influenced by Nehru's neutralism and the non-alignment movement. This policy was eventually enshrined and elaborated as the 'three peace principles' of the JSP at its January 1950 convention: (1) conclusion of a comprehensive peace treaty with the countries which were legally still in a state of war with Japan; (2) neutrality in accordance with the Constitution; and (3) opposition to the use of Japanese military bases by any foreign powers. In the following year, a fourth principle of the opposition to rearmament was added. ${ }^{49}$ Though there were periodic oscillations in the policies, the spirit of the above policies was generally observed by the Socialists.

The bedrock of JSP's policy was to champion for the cause of 'positive neutrality', and to assume for themselves the mantle of a genuine third force standing between the Communist and Capitalist blocks in order to play a positive and mediating role in encouraging a peaceful co-existence between the two social systems, and to achieve pacifism and national security through the maintenance of neutrality in a bi-polar world. On the other hand, the Communists have adopted a very ideologically oriented and Marxist outlook on the issue of pacifism. For the Communists, in order to realize the biblical dream of bending the sword into ploughs, the 'enemy of peace' must be

8 Stockwin, The Japanese Socialist Party and Neutralism, p. 31.

49 Cole, Totten and Uyehara, op. cit., p. 200. 
.

eliminated. The Communists and their sympathizers identified American imperialism as the primary enemy of peace in the world, and it must be resisted accordingly. The Communists advocated a so-called 'Peace thesis', in which the United States was lambasted as the principal threat to world peace and the Soviet Union and Red China were glorified as a 'force of peace'. In addition, the Communists also presented the nuclear disarmament and the pacifist movement in a wider context of struggle against imperialism and the national liberation movement. ${ }^{50}$ Given such radically different outlooks on the issue of pacifism, it is not surprising that the Gensuikyo became the ideological battleground for the two parties.

In the initial period of its existence, the Gensuikyo was able to remain above the partisan politics and was not identifiably aligned with the left of the political spectrum. The united front was maintained between the various leading 'progressive forces' and the pacifists without political affiliations on the basis of total prohibition against nuclear weapons and disarmament. However, this united front was short-lived, as the Gensuikyo left wing (essentially the JCP) started to infiltrate the Gensuikyo with its front organizations and started to incorporate ideologically oriented goals such as the struggle against American imperialism and support for the national liberation movement into its agenda. ${ }^{51}$

At the fourth World Conference Against Atomic and Hydrogen Bombs, the resolution approved by the Gensuikyo became visibly pro-Communist and antiAmerican, the Soviet Union was praised for its unilateral suspension of nuclear tests, the American and British military policies in the Middle East were vehemently denounced as a threat to world peace, and calls for normalization of diplomatic relations with the People's Republic of China were also made. ${ }^{52}$ Many moderates and unaffiliated groups were dismayed by the growing Communist control of the Gensuikyo, and they regarded many of the objectives advanced by the resolution as not conducive to the purposes of the movement. Many non-aligned groups felt very alienated by their experiences and lost any enthusiasm to participate in any further activities organized by the Gensuikyo.

During the late 1950s and early 1960s, The Gensuikyo fell increasingly under the control of the Communists. At the 1960 World Conference, the United States was again denounced as the principal enemy of world peace, and the abolition of nuclear weapons was only possible through the struggle against the American imperialists. The first major crisis occurred in 1961, when the Communists wanted to make the struggle against American imperialism the focal point of the movement. The Communists insisted that

\footnotetext{
Langer, Communism in Japan, pp. 119, 148.

DiFilippo, 2003, ' The Politics of Japanese Nuclear Disarmament Initiatives', pp. 4-5.

Langer, op. cit., p. 118.
} 
'enemies of peace' must be identified; the anti-nuclear movement must be propagated in the context of struggles against American imperialism and neo-colonialism. The JSP attempted to resist the Communist policy onslaught and argued that the close alliance with the Communist block and the relentless attacks on the West would violate its 'positive neutrality' principle, and it would antagonize all the moderates and reduce its mass appeal to the people. The Communists had won a Pyrrhic victory due to their superior organizational skills, and the JSP issued a strongly worded protest and asserted 'We have no confidence in the present Gensuikyo' ${ }^{53}$

The last straw came only two weeks after the $7^{\text {th }}$ World Conference, after the Soviets had conducted a series of nuclear tests. One of the seemingly innocuous resolutions passed by the Gensuikyo during the Conference was that any government that breaches the current nuclear testing moratorium will be 'denounced as the enemy of peace and of mankind, and ironically this resolution was suggested by the Soviet delegate at the Conference. The Gensuikyo was immediately engulfed in an uproar; the Communists quickly endorsed the Soviet actions and justified them on the grounds that 'since the Soviet Union is a peace force, nuclear tests are a natural defensive measure. ${ }^{54}$ The Socialists directed their ammunition at both the United States and the Soviet Union, and demanded absolute opposition to nuclear testing by any country.

After the feeble protest issued by the Gensuikyo at the $7^{\text {th }}$ World Conference against the Soviet nuclear tests, the Socialists and their allies were determined to resist Communist dominance of the movement at the $8^{\text {th }}$ World Conference and demanded a resolution that would condemn both Soviet and American nuclear tests. Once again, the Communists outmanoeuvred the Socialists and the resolution failed to pass, the infuriated Socialist delegates stormed out of the meeting. As a result of the Socialists withdrawal, the meeting descended into utter chaos. After the disastrous $8^{\text {th }}$ World Conference, the JSP and its affiliated unions started to contemplate establishing their own anti-nuclear organization. The Socialists had announced that 'positive neutrality' had to be the basis for the peace movement and a one-sided view of the problems of nuclear weapons and disarmament could not be tolerated. ${ }^{55}$ After a few interim rallies organized by the Socialists in direct competition with the JCP dominated Gensuikyo Conference, the Japan Congress against Atomic and Hydrogen Bombs (Gensuikin) was formally inaugurated in February $1965 .^{56}$

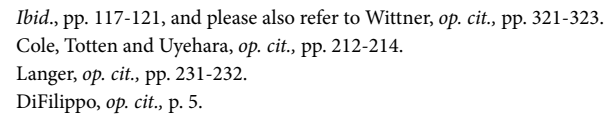


.

\section{Anti-nuclear Movement After Gensuikyo Schism}

After the departure of the Socialists and their allies, the Gensuikyo was reduced largely to its Communist constituency, and it became ever more sectarian in its policy orientation. The struggle between the JCP and the JSP over the direction and the policy of the Gensuikyo had a disastrous effect on the Japanese pacifist movement in general and the anti-nuclear movement in particular. Not only did it cause the disintegration of the world's largest anti-nuclear movement, it had done much to discredit the movement in the eyes of the Japanese public. Both movements had to rely on their core constituencies for support, the Communists and the radical left provided the muscle for the Gensuikyo and the Socialists and their allies were the steam behind the Gensuikin. It affirmed the conservatives' allegation in the public mind that the JSP and the JCP had hijacked a sacred mission for its own political gains. ${ }^{57}$

One of the biggest blows to the organised peace movement was the demise of the JSP as the largest and most influential sponsor of the peace movement. Its disbandment more or less spelt the end of the influence of socialism on the peace movement. It could be said that the post-war rasion d'etre of the JSP rested largely on its opposition to the revision of the pacifist constitution and any moves to re-arm Japan by the conservative LDP. However, the Socialists' commitment to this basic article of faith had been slowly eroding throughout the 1980s. In 1984, the party secretary Ishibashi Masashi proposed a tortured formula that recognises the legality but not the constitutionality of the SDF. ${ }^{58}$ Though it could be regarded as pragmatic recognition of the fait accompli, it was a dramatic departure of vehement and sometimes violent opposition against the SDF by the Socialists. In 1994, the most dramatic moment in JSP's history occurred and it sent a seismic shock throughout the Japanese electorate and the peace movement in particular. The JSP congress voted to renounce its most fundamental principles: the recognition of SDF's constitutionality, support for the US-Japan Security Treaty, the acceptance of the Kimigayo and Hinomaru as the national anthem and flag respectively, and the abandonment of its reservation on the development of nuclear energy. ${ }^{59}$ The JSP itself was soon dissolved as well after it had deserted all its key policies without any articulation of new replacement principles. This spectacular renunciation of faith by the Socialists ended decades long support for the peace movement, and the disappearance of the JSP as the most important political actor in opposition to constitutional amendment cast an ominous shadow on the future of the peace movement in Japan, effectively ending the strong left-wing influence on the peace movement.

Stockwin, 1986, 'Does Japan Have a Special Attitude to Peace?', p. 6.

McCormack, The Emptiness of Japanese Affluence, p. 211.

59 Ibid., pp. 213-215. 


\section{Conclusion}

The edifice of pacifism in post-war Japan rested largely on three important pillars: the prevailing victim consciousness among the Japanese populace, a thoroughly reformed educational system that repudiated militarism and the strong organisational and political support for the organised peace movement by the leftist forces. The suffering of the Japanese people, especially in the nuclear holocausts of Hiroshima and Nagasaki seared into the national consciousness an abiding enmity to militarism and the collective desire for a future free of war. A myth of victimhood was developed through 'scar' literature, 'never again' became the watchword of pacifism. The democratisation of the Japanese educational system laid the solid foundation for the development of a more enduring pacifism based on a critical appreciation of Japan's past as a victimiser. The unadulterated peace education during the early post-war period was responsible for the creation of a generation of politically-conscious Japanese dedicated to pacifism. Leftists' involvement in the mass peace movement provided it with a more durable character: the discipline and organisational skills of leftist forces institutionalised the anti-nuclear movement after cooling of initial public enthusiasm.

The generational change in Japan slowly eroded the foundation of pacifism built on victimhood. Post-war economic prosperity largely rendered the tales of hardship and sufferings incomprehensible to a youth who had only known affluence. Such an occurrence could have been rectified, if the conservative government did not compromise the peace education initiated in the post-war reforms. The government in favour of a more nationalistic curriculum implicitly censored the more critical appraisal of the war in school textbooks, thus creating a selective historical amnesia that was detrimental to fostering a peace-loving spirit. The ideologically driven involvement of leftist forces in the anti-nuclear campaign compromised its non-partisan reputation, thus reducing its overall mass appeal. The gradual demise of leftist sponsorship of the organised peace movement resulted in the declining activism of the movement.

Generational change is perhaps the greatest enemy of pacifism in Japan, especially in the absence of an effective transmission mechanism that could convey pacifist messages from one generation to another. Generational change in Japan saw not only youth without any sense of a victim consciousness, but also a generation of teachers devoid of the sense of mission to educate the next generation of the barbarism of war that was a characteristic of their predecessors. Unlike western pacifism rooted in religious tradition, Japanese pacifism was built on the shifting sands of fear-induced aversion to war. The root cause of the decline in pacifism is the fragility of its foundation. 
New Voices Volume 2

\section{References}

Asahi Shimbun Nanken (Tokyo: Asahi Shimbun, 1954).

Aspinall, R. W., Teachers' Unions and the Politics of Education in Japan (Albany: State University of New York Press, 2001).

Atomic Bomb Museum 2005, Pursuit of Peace, Retrieved 26 July 2006, from http://www.atomicbombmuseum.org/5_ begginings.shtml.

Beauchamp, E. R. \& Vardaman, J. M. Jr. (eds.), Japanese Education Since 1945: A Documentary Study (Armonk, New York: M.E. Sharpe, 1997).

Beauchamp, E. R., (ed.) Windows on Japanese Education (New York: Greenwood Press, 1991).

Brock, P., Pacifism: In Europe to 1914, (Princeton: Princeton University Press, 1972).

Buruma, I., Wages of Guilt: Memories of War in Germany and Japan (London: Vintage, 1994).

Cole, A. B., Totten, G. O., \& Uyehara, C. H., Socialist Parties in Postwar Japan (New Haven: Yale University Press, 1966).

Committee for the Compilation of Materials on Damage caused by the Atomic Bombs in Hiroshima and Nagasaki, comp., Hiroshima and Nagasaki: the Physical, Medical, and Social Effects of the Atomic Bombings (New York: Basic Books, 1981).

Cummings, W. K., Education and Equality in Japan (Princeton: Princeton University Press, 1980).

DiFilippo, A., 2003, 'The Politics of Japanese Nuclear Disarmament Initiatives: Where Government policies and Civil Society Converge and Diverge', Arms Control and Disarmament Lessons Learned and Future Prospects, Portland, Oregon.

Dower, J. D., Japan in War and Peace: Selected Essays (New York: New Press, 1993).

Duke, B. C., Japan's Militant Teachers: A History of the Left-Wing Teachers' Movement (Honolulu: The University Press of Hawaii, 1973).

French, H., 'Teaching Youth To Start Worrying About The Bomb', New York Times, 29 May 2003.

Gerson, J., With Hiroshima Eyes: Atomic War, Nuclear Extortion and Moral Imagination (Philadelphia: New Society Publishers, 1995).

Horio, T., Edited and Translated by Platzer, S., Educational Thought and Ideology in Modern Japan: State Authority and Intellectual Freedom (Tokyo: Tokyo University Press, 1988).

Howes, J. F. \& Bamba, N. (eds.), Pacifism in Japan: the Christian and Socialist Tradition (Kyoto: Minerva Press, 1978).

Ibuse, M., (translated by John Bester) Black Rain (Tokyo: Kodansha International, 1969).

Ienaga, S., (translated by Frank Baldwin) Japan's Last War: World War II and the Japanese, 1931-1945 (Canberra: Australian National University Press, 1979).

Khan, Y., Japanese Moral Education Past and Present (London: Associated University Press, 1997). 
Langer, P. F., Communism in Japan: A case of Political Naturalization (Stanford: Hoover Institute Press, 1972).

McCormack, G., The Emptiness of Japanese Affluence (Armonk, New York: M.E.Sharpe, 1996).

Ministry of Education, Science and Culture (Government of Japan), 'Japan's Modern Educational System: A History of the First Hundred Years', Tokyo, Japan.

Naeve, V., Friends of Hibakusha (Denver: Alan Swallow, 1964).

Nozaki, Y. \& Inokuchi, H., Japanese Education, Nationalism and Ienaga Saburo's Textbook Lawsuits in Hein, L. \& Selden, M., Censoring History: Citizenship and Memory in Japan, Germany, and the United States (Armonk, London: M.E.Sharpe, 2000).

Okano, K. \& Tsuchiya, M., Education in Contemporary Japan: Inequality and Diversity (Cambridge: Cambridge University Press, 1999).

Orr, J., The Victim as Hero: Ideologies of Peace and National Identity in Post-war Japan (Honolulu: University of Hawaii Press, 2001).

Reedy, S. M., Mechanism of State Control: An Historical Study of the Treatment of the Pacific War in Japanese High School History Books from 1945 to 1995 (unpublished Doctor of Education thesis), the University of San Francisco: California, 1999.

60 Years since the Atomic Bombing: Time to Develop Actions and Cooperation for a Nuclear Weapon-Free, Peaceful, Just World, 2005, the 2005 World Conference against A \& H Bombs, Hiroshima, Japan.

Stockwin, J.A.A., The Japanese Socialist Party and Neutralism: A Study of a Political Party and Its Foreign Policy (Melbourne: Melbourne University Press, 1968) p. 31.

Stockwin, J.A.A., 'Does Japan Have a Special Attitude to Peace?' Oxford Project for Peace Studies, Occasional Paper No 2, Oxford, UK, 1986.

Stockwin, J.A.A., Dictionary of the Modern Politics of Japan (London: RoutledgeCurzon, 2003), p. 123.

Tanaka, Y., 2005, The Hibakusha Voice and the Future of the Anti-Nuclear Movement, Japan Focus. Retrieved 2 February 2005, from http://japanfocus.org/_Yuki_TANAKA__The_Hibakusha_Voice_and_the_Future_of_the_Anti_ Nuclear_Movement.

Thakur, Y. H., History Textbook Reform in Allied occupied Japan, 1945-52 in Beauchamp, E R., Dimensions of Contemporary Japan: A Collections of Essays (New York: Garland Publishing, 1998).

The Centre for Strategic and International Studies, Generational Change in Japan: Its Implication for U.S-Japan Relations 2002, Washington.

The Chinese victims and their Japanese helpers: Phoenix TV 2005, a series to commemorate the $60^{\text {th }}$ anniversary of WWII.

The Official Website of Gensuikyo. Retrieved 5 July 2005, from http://www10.plala.or.jp/antiatom/html/e/discription gensuikyo.htm.

Thurston D. R., Teachers and Politics in Japan (Princeton: Princeton University Press, 1973). 
.n.m.n.m \&

Thurston, D. R., “The decline of the Japan Teachers Union” in Journal of Contemporary Asia, Vol. 19 No 2, (1989).

Tsuchimochi, G. H., Education Reform in Postwar Japan: the 1946 U.S Education Mission (Tokyo: Tokyo University Press, 1993).

Whittier Treat, J., Writing Ground Zero: Japanese literature and the Atomic Bomb (Chicago: The University of Chicago Press: 1995).

Wittner, L. S., Resisting the Bomb: A History of the World Nuclear Disarmament Movement, 1954-1970 (California: Stanford University Press, 1997). 